\title{
Development of Analytical Method for the Detection of Nemacur Residues in Cucumber Fruits
}

\author{
Said Al-Kurdi, Mohammed 0. Alloh, Mohammed R. Al-Agha, Yasser El-Nahhal ${ }^{*}$ \\ Department of Earth and Environmental Sciences, Faculty of Science, The Islamic University, Gaza, Palestine \\ Email: *y_el_nahhal@hotmail.com
}

How to cite this paper: Al-Kurdi, S., Alloh, M.O., Al-Agha, M.R. and El-Nahhal, Y. (2018) Development of Analytical Method for the Detection of Nemacur Residues in Cucumber Fruits. American Journal of Analytical Chemistry, 9, 64-76.

https://doi.org/10.4236/ajac.2018.91006

Received: December 13, 2017

Accepted: January 22, 2018

Published: January 25, 2018

Copyright $\odot 2018$ by authors and Scientific Research Publishing Inc. This work is licensed under the Creative Commons Attribution International License (CC BY 4.0).

http://creativecommons.org/licenses/by/4.0/

\begin{abstract}
Application of Nemacur (Fenamiphos) for pest control may contaminate soil, water and plant with harmful residues and pose threats to human life. This study developed an easy method for the determination of Nemacur residues in cucumber fruits collected from the central markets and from the farm. The method is based on extracting the active ingredients of Nemacur from the commercial formulation and used as a standard material to calibrate the HPLC to determine Nemacur residues in cucumber fruits collected from the central market. Results showed that more than $70 \%$ of the active ingredient was extracted from the commercial formulations. Standardization of HPLC with extracted materials showed strong positive association between concentration and peak area relationship. Bioassay investigation showed high mortality of tested organism (fish). Statistical analysis of mortality \% between the commercial formulation and those of the extracted ingredient showed no significant differences. These results demonstrated the effectiveness of extracted Nemacur to calibrate HPLC and in bioassay test. Nemacur residues in $\mathrm{Cu}$ cumber fruits collected from the market were below the detection limit of HPLC, recovery \% of Nemacur from control group of cucumber was above $80 \%$. It can be concluded that the method is easily developed and validated by bioassay and chemo-assay.
\end{abstract}

\section{Keywords}

Nemacur, Fenamiphos, Analytical Method, HPLC

\section{Introduction}

Application of pesticides in Gaza strip Palestine is progressively increased due to 
the intensive agricultural activity. The use of pesticides has been associated with pesticide residues in fruits and vegetables [1] [2] [3]. Furthermore, contamination of food with pesticide residues has created many health problems such as cancer cases [4] [5], biochemical changes among farmers [6], obstructive polumery disease among green house farmers [7], poisoning cases among farmers [8] and suicidal attempts among general population [9]. So far, application of pesticides has damaged the eco-system elsewhere [10], destroyed fish population [11] [12] [13], had toxicity to cyanobacterial mats [14] [15] [16] [17]. Nemacur was chosen because it is widely used in Gaza for insects and weed control and their application is associated with health damage to farmers [18]. Chemo-assay of pesticides residues using GC and HPLC is well known and widely used techniques for pesticide determination in fruits and vegetables. These techniques some times are not able to detect low concentrations of pesticides. Furthermore, few studies used bioassay techniques for pesticide residues analysis, which included test plant assay [19] [20] enzymatic assay such as using choline esterase as a biomarker for organophosphorus insecticides [21]. The limitations of the above mentioned methods are that they used ultra-pure technical materials of pesticides to prepare the standard solutions for the laboratory scale for determining residues in environmental samples. Currently, there are many difficulties in Gaza Strip, Palestine to purchase technical materials at high purity (99.5\%) for pesticide residue analysis in vegetable, fruits and water systems due to the current political situation. In addition, determination of pesticide residues in the absence of pure materials was poorly investigated or remained untested. Our objective in this study was to use the commercial formulation for extracting the active ingredient and to further purify it through crystallization and to use the pure crystals to calibrate the HPLC machine for determining Nemacur residues in cucumber fruits collected from the market and field.

\section{Materials and Methods}

\subsection{Study Area}

Gaza strip is a semi-arid zone with large agricultural activity in green house technology. Gaza Strip is an important part of State of Palestine. It consists of five Governorates, the northern area, Gaza, the middle (Deir al-blah), Khan Yunis and Rafah Governorates. It is one of the most densely populated areas in the world (2638 people $/ \mathrm{km}^{2}$ ), has limited and declining resources and has already started to experience deterioration of environmental quality. Two thirds of the Gaza Strip (total $365 \mathrm{~km}^{2}$ ) is an agricultural area [22]. The global and local coordination (GPS) were specified as shown in Table 1.

Application of Nemacur tends to increase due to the intensive agricultural application. In Table 2 we demonstrate the use of pesticides by their functions.

Nemacur is an organophosphorus compound with a molecular weight 303.4, its solubility in water is about $0.4 \mathrm{~g} / \mathrm{L}$. It is a solid material at room temperature with a milting point $49^{\circ} \mathrm{C}$. It has a pKa value of 10.5 , and has a Henry's Law 
constant at $20^{\circ} \mathrm{C}$ equal $9.1 \times 10^{-5} \mathrm{~Pa} \mathrm{~m} / \mathrm{mol}$, Tomlin [23]. Molecular structure is shown in Figure 1.

\subsection{Analytical Method}

Commercial formulation (emulsifiable concentrate) containing $40 \%$ of active ingredient of was purchased from a certified pesticide shop in Gaza Strip, Palestine. So far, Nemacur, is originally from Dow Agro Sciences Co., USA.

Following the procedure described previously [24], a $10 \mathrm{~mL}$ of commercial Nemacur were suspended in $90 \mathrm{~mL}$ of water to form $100 \mathrm{ml}$, and shacked very<smiles>CCOP(=O)(NC(C)C)Oc1ccc(SC)c(C)c1</smiles>

Figure 1. Molecular structure of Nemacur.

Table 1. Global and palestinian coordinates.

\begin{tabular}{|c|c|c|c|c|}
\hline \multirow{2}{*}{ Sample } & \multicolumn{2}{|c|}{ UTM WGS 84-Coordinates } & \multicolumn{2}{|c|}{ Palestine grid Coordinates } \\
\hline & East & North & East & North \\
\hline Sandy soil & $34^{\circ} 20^{\prime} 41^{\prime \prime} \mathrm{E}$ & $31^{\circ} 24^{\prime} 17^{\prime \prime} \mathrm{N}$ & $87682.00 \mathrm{E}$ & $90620.00 \mathrm{~N}$ \\
\hline Clay soil & $34^{\circ} 20^{\prime} 25^{\prime \prime} \mathrm{E}$ & $31^{\circ} 24^{\prime} 22^{\prime \prime} \mathrm{N}$ & $87274.00 \mathrm{E}$ & $90774.00 \mathrm{~N}$ \\
\hline
\end{tabular}

Application of Nemacur tends to increase due to the intensive agricultural application. In Table 2, we demonstrate the use of pesticides by their functions.

Table 2. Quantities of pesticides (liter) used in Gaza Strip in the past years.

\begin{tabular}{ccccccc}
\hline Year & H & I & F & F \& H & Total (L) & N \\
\hline 2005 & 20,440 & 56,714 & 74,336 & 980 & 453,170 & NA \\
2006 & 24,940 & 55,270 & 55,650 & 855 & 248,315 & NA \\
2007 & 18,800 & 35,580 & 34,270 & 3500 & 185,950 & NA \\
2008 & 18,200 & 49,650 & 42,200 & 60,828 & 364,478 & NA \\
2009 & 39,432 & 139,337 & 123,694 & 10,771 & 711,802 & 18,120 \\
2010 & 18,780 & 144,682 & 99,630 & 61,327 & 486,819 & 13,836 \\
2011 & 27,054 & 220,169 & 136,477 & 7429 & 484,164 & 30,440 \\
2012 & 25,609 & 232,488 & 137,911 & 5209 & 544,427 & 19,968 \\
2013 & 24,251 & 180,664 & 104,705 & 8577 & 443,887 & 23,015 \\
2014 & NA & NA & NA & NA & NA & 27,618 \\
2015 & NA & NA & NA & NA & NA & 39,355 \\
\hline
\end{tabular}

$\mathrm{H}=$ Herbicides, $\mathrm{I}=$ insecticides, $\mathrm{F}=$ fungicides, $\mathrm{F} \& \mathrm{H}=$ fumigants and hormones, $\mathrm{N}=$ Nemacur. All amounts are in liters Adopted from Ministry of Agriculture [25]. 
well to form an emulsion. $10 \mathrm{ml}$ of the emulsion was transferred to the extraction tube containing $10 \mathrm{ml}$ dichloromethane. Then the mixture was vortexed at high speed for $3 \mathrm{~min}$. The mixture was left for 1 hour until an organic layer was formed. The organic layer was removed in a $50 \mathrm{ml}$ flask. Then the extraction procedure was repeated three times in total to insure complete extraction of pure ingredient of Nemacur. The total volume of extract, $28 \mathrm{ml}$ organic layer, was dried using anhydrous sodium sulfate. Then dichloromethane was evaporated under stream of nitrogen gas, and the residue was recrystallized using methanol. The white solid was collected by filtration. The purity of Nemacur was tested using HPLC and bioassay. And Methanol of HPLC grade, purity $99.9 \%$ was purchased from Sigma Aldrich Co., Germany, was purchased from Gaza.

\subsection{HPLC-Measurement}

HPLC (Agilent 1620) analyses were performed on isocratic system [26]. Nemacur concentrations in the supernatant were determined by Diode Array Detector (DAD) equipped with manual-injection system. The column was Reversephase. Packing ODS-BP5 $\mu \mathrm{m}$ (C18), and a $150 \mathrm{~mm} \times 4.6 \mathrm{~mm}$ (i.d.). Injection volume is $50 \mu \mathrm{l}$ and wave length of detection was $250 \mathrm{~nm}$, Mobile phase is water: methanol 20:80. The flow rate was maintained at $2 \mathrm{ml} \cdot \mathrm{min}$. other conditions were as used for the silica gel column. External calibration was used for quantification of Nemacur.

\subsection{Standard Curve of Nemacur}

As described previously [27] [28] [29] [30], concentration-peak area relationships were established in the range on $0.0-1 \mathrm{mg} / \mathrm{L}$. The absorption was measured by HPLC at wavelength $250 \mathrm{~nm}$ and retention time $2.004 \mathrm{~min}$.

\subsection{Nemacur Recovery Test from Cucumber}

A one $\mathrm{kg}$ cucumber of cucumber was mixed and homogenized with $2 \mathrm{mg}$ pure Nemacur (collected from the extracted materials mentioned above). Then, three sets of $10 \mathrm{~g}$ homogenate were collected severalty and used from Nemacur extraction from fruit following the previous method [31] [32]. The extracts were then analyzed by our method as shown below.

\subsection{Control Group}

A one kg cucumber of cucumber from the same market was mixed homogenized using a blinder. Then, three sets of $10 \mathrm{~g}$ homogenate were collected severalty and extracted for possible Nemacur residues following the procedure described above. The extracts were then analyzed by our method as shown below.

\subsection{Nemacur Bio-Activity Test}

The bioactivity of Nemacur was tested against fish larvae, have $5 \pm 0.5 \mathrm{~g}$ body weight each according to previous report [33] [34]. The tested concentrations were in the range of $0.0,0.004,0.04,0.4,0.8,1.6 \mathrm{mg} / \mathrm{L}$. Mortality of fish was de- 
termined according to previous reports [35].

\subsection{Cucumber Planting}

Sandy and clay soil samples were collected of an agricultural area have at least five years history free from Nemacur application. The selected soil samples were dried for $48 \mathrm{~h}$, and then passed through a $2-\mathrm{mm}$ sieve, as described in study by [35] [36] [37] [38]. Two sets of 16 pots each set, were filled with sandy and clay soil. The volume of each pot is $10 \mathrm{~L}$. Cucumber seedlings were planted in the sandy and clay soil in 32 pots, then transferred to the greenhouse to protect the seedlings from the weather conditions. Nemacur was applied at $0.0,0.5 \mathrm{~F}, 1 \mathrm{~F}$, and $2 \mathrm{~F}$, where $\mathrm{F}$ is the field rate which equal $2 \mathrm{~L} / 1000 \mathrm{~m}^{2}$. The field concentration was calculated for each pot according to surface area for the pot [39] [40] [41] [42]. The concentrations are as follows, $0.0,6.59,13.17,26.35 \mathrm{mg} / \mathrm{kg}$ soil respectively. Four replicates were used for each concentration in both soil types. The pots were irrigated with $8.5 \mathrm{~L}$ of water during the growth season (3 months). Cucumber plant had a normal growth under a normal condition at specified greenhouse.

\subsection{Fruits Collection}

Cucumber fruit were harvested from the plants whenever it reached $10 \mathrm{~cm}$ long, or $2 \mathrm{~cm}$ in diameter. The fruits of each treatment were mixed together to form a complex sample. Then a one kg sample was taken, cut, grounded and homogenized. Then $10 \mathrm{~g}$ was extracted with mixture of organic solvent [43] [44] [45] and analyzed by HPLC. Furthermore, cucumber fruits were also collected from the central market in deir al-balah. Six samples of cucumber fruits were collected randomly from the market. The samples were transferred to the laboratory and prepared as described above for analysis on HPLC and bio-assay as mentioned above.

\subsection{Statistical Analysis}

Average and standard deviation of Nemacur concentrations were calculated for each sample. T-test was used to detect significant differences among treatment at p-value $=0.05$.

\section{Results and Discussion}

\subsection{Extracted Nemacur}

It appeared that more than $80 \%$ of Nemacur was extracted from the commercial formulation indicating the efficacy of extraction. So far the extracted material was pure and has a while color similar to those described by Tomlin [23]. These materials were collected in glass tube and used as ultra-pure to calibrate the HPLC and for bio-assay test.

\subsection{UV Spectrum of Extract Nemacur}

The UV spectrum of extract Nemacur is shown in Figure 2. The presented data 


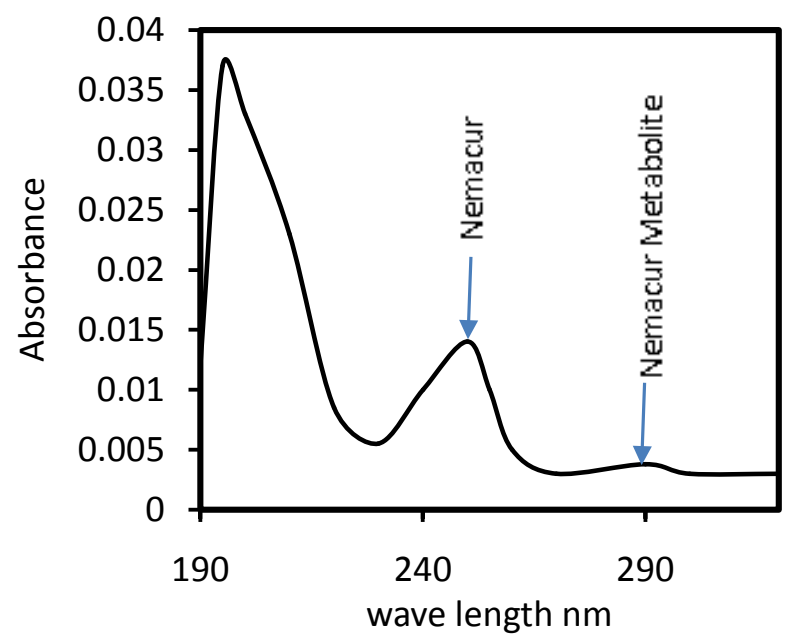

Figure 2. Absorbance spectrum of Nemacur as shown by UVspectroscopy. A sharp peak is obvious at $250 \mathrm{~nm}$ with a reduced peak at $280 \mathrm{~nm}$.

clearly showed the absorbance spectrum of Nemacur extracted from the commercial formation. It is obvious that a strong peak appeared at wave length 250 $\mathrm{nm}$ with a reduced peak at $280 \mathrm{~nm}$. This indicates strong absorption spectra at the uv-range. Our results agree with AOAC method (1995) which revealed that fenamiphos and its sulfoxide and sulfone metabolites can be detected by UVdetection. Furthermore, this method of validation is similar to that obtained by Ref [46] [47] [48] for other cases. Furthermore, the HPLC chromatogram (Figure 3) shows a sharp peak at low convention, indication of the sensitivity of the method. According to these observations, Nemacur concentrations in cucumber were determined at $250 \mathrm{~nm}$.

\subsection{HPLC-Chromatogram of Nemacur}

An HPLC chromatogram of Nemacur is shown in Figure 3. It is obvious that a sharp peak with considerable peak area were obtained at $2.043 \mathrm{~min}$. This indicates the accuracy of the used method for determination.

So far, the appeared peak at $250 \mathrm{~nm}$ after $2 \mathrm{~min}$ of retention time, indicates the validation $\mathrm{n}$ of our method. Regardless, to nearly short retention time, Nemacur was detected normally without any interference with the solvent. Nevertheless, it is possible to increase the retention time to be after $4 \mathrm{~min}$ by increasing water \% from 20 to 40 in the mobile phase. However, no interfering peaks (metabolites or other pollutants) appeared with Nemacur so that the analytical procedure went smoothly.

In addition, the relationship between peak area and gradient concentrations of Nemacur showed a linear relationship (Figure 4). This indicates strong positive association between concentration and peak area. Regression analysis showed a correlation coefficient $\left(\mathrm{R}^{2}\right)$ of 0.9951 . This linearity indicates the validity and the suitability of the used method and allows direct measurements of Nemacur in 


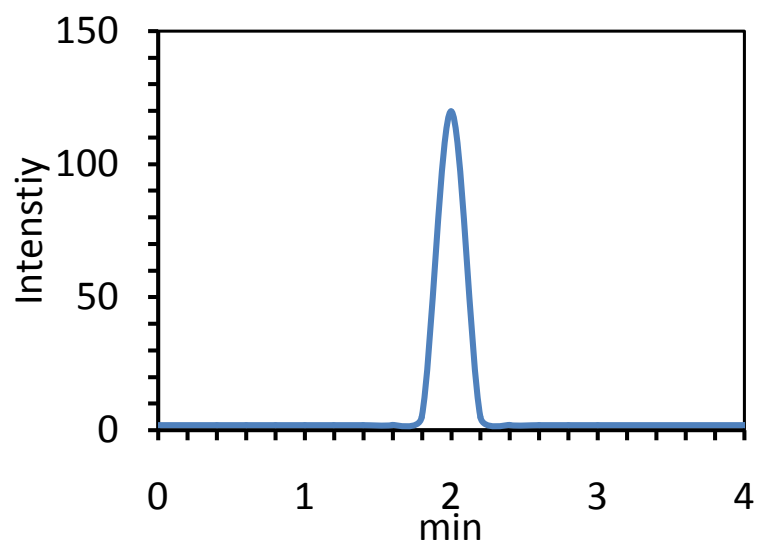

Figure 3. HPLC-Chromatogram of Nemacur after two min. of retention time in methanol water 80:20 ration and one $\mathrm{ml} /$ $\min$.

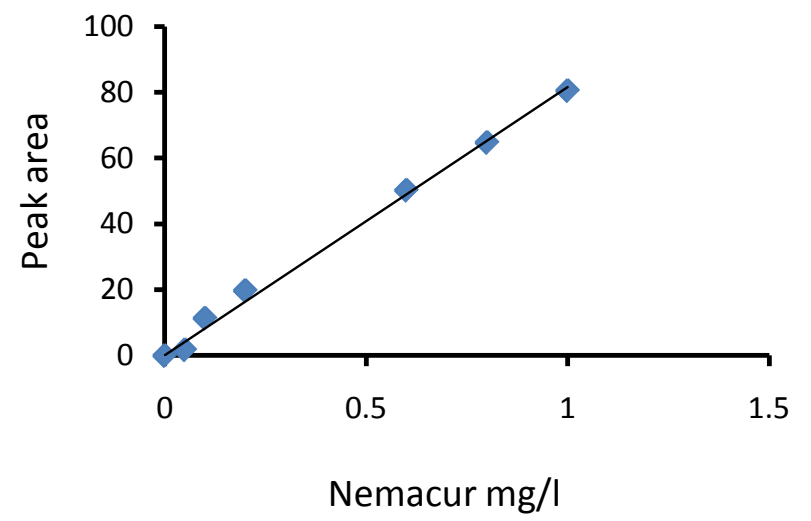

Figure 4. Relationship between peak area and standard concentration of Nemacur.

the supernatants by HPLC. Similar results were obtained for other cases [49] [50].

\subsection{Bioassay Technique (Mortality Test)}

The idea stands behind this test is to insure the biological activity of Nemacur at various concentration. Furthermore, fish was used as a test organism due to high sensitivity. There has been a progressive increase between fish mortality and gradient concentration of Nemacur. 100\% fish mortality was observed at $1 \mathrm{mg} / \mathrm{L}$ (Data not shown). The effect can be visualized in Figure 5. It is obvious that mortality of fish is high in all tested concentrations. This mortality of fish is due to inhibition of acetylcholinesterase by Nemacur. Toxicity of organophosphorus insecticides to fish has previously been reported [51] [52] [53] [54].

\subsection{Nemacur Residues in Cucumber}

Nemacur residues in cucumber collected from the central market and from two different fields are shown in Table 3. 


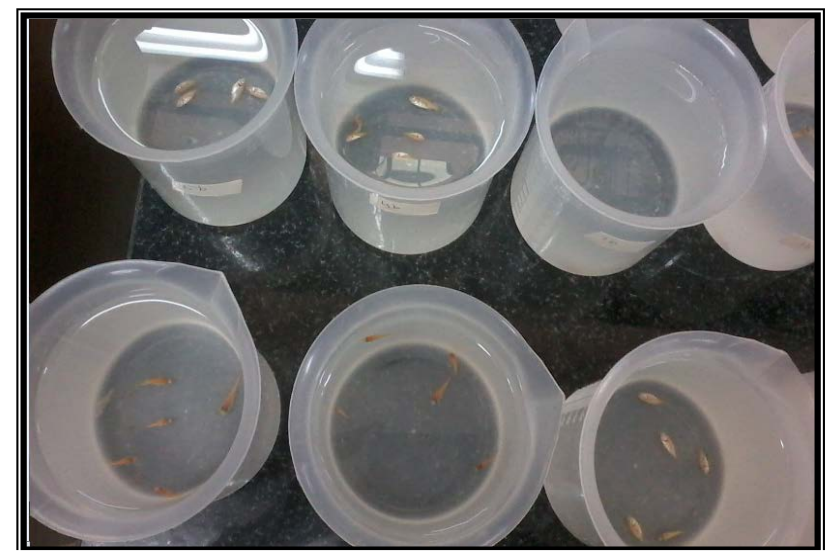

Figure 5. Visual rating of fish mortality as exposed to low concentrations of Nemacur extracted from commercial formulation.

Table 3. Concentration of Nemacur $(\mathrm{mg} / \mathrm{kg})$ in cucumber fruits.

\begin{tabular}{|c|c|c|c|}
\hline \multirow{3}{*}{$\begin{array}{c}\text { Cucumber } \\
\text { Harvesting date }\end{array}$} & \multicolumn{3}{|c|}{ Nemacur mg/kg } \\
\hline & \multirow{2}{*}{ Market sample } & \multicolumn{2}{|c|}{ Field sample } \\
\hline & & Clay soil & Sandy soil \\
\hline $1^{\text {st }}$ harvest (30 day) & $\mathrm{BD}$ & $\mathrm{a} 0.24 \pm 0.17$ & $\mathrm{a} 0.74 \pm 0.13$ \\
\hline $2^{\text {nd }}$ harvest 45 day & $\mathrm{BD}$ & $\mathrm{b} 1.93 \pm 0.46$ & $\mathrm{~b} 1.60 \pm 0.61$ \\
\hline
\end{tabular}

It can be seen that market samples have Nemacur concentration below detection limit of the HPLC whereas cucumber fruits of the experiment have nearly high concentrations. So far the concentrations of $1^{\text {st }}$ harvest are lower than the $2^{\text {nd }}$ harvest in both soils. The explanation of these results is that the market samples were not sprayed with Nemacur during the growth season or the values are below the detection limit. Moreover, the lower values of the $1^{\text {st }}$ harvest fruits can be explained by the fact that accumulation on Nemacur in cucumber fruits is a function on plant age, younger plant contains lower concentration than older plant due to high exposure time, as Nemacur tend to accumulate in the root zone and be absorbed by plant root in due time. This explanation agrees previous reports [55] [56] [57] [58] which found similar results with other cases. Furthermore, cucumber fruits in the sandy soil have higher concentration than clay soil in the $1^{\text {st }}$ harvest and the opposite is right in the $2^{\text {nd }}$ harvest. These results are explained by the fact that clay has adsorption capacity than sand, accordingly low fraction of Nemacur is available for plant absorption consequently low fraction of Nemacur was accumulated in the $1^{\text {st }}$ harvest. After 45 days, $2^{\text {nd }}$ harvest, clay reached to the maximum adsorption capacity, then Nemacur tends to accumulate in soil solution and be absorbed by plant. In this case high concentration was accumulated in plant fruits. These results agree with previous 
reports [59]-[65] which revealed the adsorption capacity of clays in due time.

\section{Conclusion}

The present study developed an easy applicable method. The results demonstrated high extracted amount on Nemacur and its purification procedure. The biological activity of extracted Nemacur was similar to the commercial formulation, indicating the efficacy of extraction procedure. Testing the method enabled determination of Nemacur in different cucumber samples. Considerable concentration of Nemacur was found in all extracted tested samples. The result revealed lower concentrations of Nemacur in cucumber collected in the $1^{\text {st }}$ harvest than the $2^{\text {nd }}$ harvest. Nemacur residues do not appear in random samples taken from the market. It is recommended to use this method for determining pesticide residues in fruits and vegetables to save the cost and to reduce time of waiting to purchase ultra-pure active ingredient of pesticides.

\section{Acknowledgements}

Prof. Dr. El-Nahhal would like to thank AvH-Foundation, Germany for funding several research stays in German Universities. Special thanks go to Hunaif laboratory team for helping in the biochemical analysis.

\section{References}

[1] Safi, J.M., Abou-Foul, N.S., El-Nahhal, Y.Z. and El-Sebae, A.H. (2002) Monitoring of Pesticide Residues on Cucumber, Tomatoes and Strawberries in Gaza Governorates, Palestine. Molecular Nutrition/Food Research, 46, 34-39. https://doi.org/10.1002/1521-3803(20020101)46:1<34::AID-FOOD34>3.0.CO;2-W

[2] El-Nahhal, Y. (2004) Contamination and Safety Status of Plant and Food in Arab Countries. Journal of Applied Sciences, 4, 411-417. https://doi.org/10.3923/jas.2004.411.417

[3] El-Nahhal, Y. and Safi, J. (2012) Removal of Organic Pollutants from Water by Modified Bentonite. Pesticides-Advances in Chemical and Botanical Pesticides, Chapter 5, 93-102.

[4] Safi, J.M., El-Nahhal, Y.Z., Soliman, S.A. and El-Sebae, A.H. (1993) Mutagenic and Carcinogenic Pesticides Used in the Agricultural Environment of Gaza Strip. Science of the Total Environment, 132, 371-380. https://doi.org/10.1016/0048-9697(93)90145-V

[5] El-Nahhal, Y. and Radwan, A. (2013) Human Health Risks: Impact of Pesticide Application. Journal of Environment and Earth Science, 3, 199-209.

[6] El-Nahhal, Y. (2016) Biochemical Changes Associated with Long Term Exposure to Pesticide among Farmers in the Gaza Strip. Occupational Diseases and Environmental Medicine, 4, 72. https://doi.org/10.4236/odem.2016.43009

[7] El-Nahhal, Y. (2017) Acute Poisoning among Farmers by Chlorpyrifos: Case Report from Gaza Strip. Occupational Diseases and Environmental Medicine, 5, 47-57. https://doi.org/10.4236/odem.2017.52005

[8] Al-Arifi, S.N., Al-Agha, R.M. and El-Nahhal, Z.Y. (2013) Hydrogeology and Water Quality of Umm Alradhma Aquifer, Eastern Saudi Arabia. Journal of Environment and Earth Science, 3, 118-127. 
[9] El-Nahhal, Y. (2017) Suicidal Attempt Using Racumin: A Case Report. Open Access Journal of Toxicology, 2, 1-3.

[10] Environmental Protection Agency (EPA) (2013) Safely Using Insecticides Containing Fenamiphos on Plants.

[11] El-Nahhal, Y., El-Najjar, S.H. and Afifi, S. (2015) Impact of Organic Contamination on Some Aquatic Organisms. Toxicol. Int, 22, 45-53. https://doi.org/10.4103/0971-6580.172256

[12] El-Nahhal, Y. and El-Dahdouh, N. (2015) Toxicity of Amoxicillin and Erythromycin to Fish and Mosquito. Ecotoxicology and Environmental Contamination, 1, 13 21.

[13] El-Nahhal, Y., Abadsa, M. and Affifi, S. (2014) Leaching Potential of Diuron and Linuron in Gaza Soils. American Journal of Plant Sciences, 5, 4040. https://doi.org/10.4236/ajps.2014.526422

[14] Abed, M.A., Safi, M.N., Köster, J., Beer, D., El-Nahhal, Y., Rullkötter, J. and GarciaPichel, F. (2002) Microbial Diversity of a Heavily Polluted Microbial Mat and Its Community Changes Following Degradation of Petroleum Compounds. Applied Environmental Microbiology, 68, 1674-1683. https://doi.org/10.1128/AEM.68.4.1674-1683.2002

[15] El-Nahhal, Y., El-dahdouh, N., Hamdona, N. and Alshanti, A. (2016) Toxicological Data of Some Antibiotics and Pesticides to Fish, Mosquitoes, Cyanobacterial Mats and to Plants. Data in Brief, 6, 871-880. https://doi.org/10.1016/j.dib.2016.01.051

[16] El-Nahhal, Y. and Hamdona, N. (2015) Phytotoxicity of Alachlor, Bromacil and Diuron as Single or Mixed Herbicides Applied to Wheat, Melon, and Molokhia. SpringerPlus, 4, 367. https://doi.org/10.1186/s40064-015-1148-7

[17] El-Nahhal, Y. and El-Hams, S. (2017) Effects of Bromacil, Malathion and Thiabendazole on Cyanobacteria Mat Growth. International Journal of Applied Science: Research and Review, 4, 1. https://doi.org/10.21767/2349-7238.100053

[18] El-Nahhal, Y. (2017) Risk Factors among Greenhouse Farmers in Gaza Strip. Occupational Diseases and Environmental Medicine, 5, 1-10. https://doi.org/10.4236/odem.2017.51001

[19] El-Nahhal, Y. (2004) Leaching Behavior of Metolachlor in Soil. Journal of Environmental Engineering \& Science, 3, 187-194. https://doi.org/10.1139/s03-075

[20] El-Nahhal, Y. (2003) Persistence, Mobility, Efficacy and Safety of Chloroacetanilide Herbicide Formulation under Field Conditions. Environmental Pollution, 124, 33 38. https://doi.org/10.1016/S0269-7491(02)00431-1

[21] Ben Oujji, N., Bakas, I., Istamboulié, G., Ait-Ichou, I., Ait-Addi, E., Rouillon, R. and Noguer, T. (2012) Acetylcholinesterase Immobilized on Magnetic Beads for Pesticides Detection: Application to Olive Oil Analysis. Sensors, 12, 7893-7904. https://doi.org/10.3390/s120607893

[22] Ministry of Agriculture (MOA) (2014) Statistical Records (2014) on Pesticides Use in Gaza. Unpublished Report, Gaza, Palestine.

[23] Tomlin, S.C. (2000) The Pesticide Manual. 12th Edition, British Crop Protection Council, Surry.

[24] El-Nahhal, Y., Bayan, W. and EL-Kurdi, S. (2016) Adsorption-Leaching Potential of Chlorpyrifos from Different Organo-Clay. Journal of Encapsulation and Adsorption Sciences, 6, 91-108. https://doi.org/10.4236/jeas.2016.63008

[25] Ministry of Agriculture (MOA) (2016) Statistical Records (2009-2015) on Nemacur Use in Gaza. Unpublished Report, Gaza, Palestine. 
[26] El-Nahhal, Y., Lagaly, G. and Rabinovitz, O. (2005) Organoclay Formulations of Acetochlor: Effect of High Salt Concentration. Journal of Agricultural and Food Chemistry, 53, 1620-1624. https://doi.org/10.1021/jf040383a

[27] El-Nahhal, I., Al-Najar, H. and El-Nahhal, Y. (2014) Physicochemical Properties of Sewage Sludge from Gaza. International Journal of Geosciences, 5, 586-594. https://doi.org/10.4236/ijg.2014.56053

[28] El-Nahhal, I., Al-Najar, H. and El-Nahhal, Y. (2014) Cations and Anions in Sewage Sludge from Gaza Waste Water Treatment Plant. American Journal of Analytical Chemistry, 5, 655-665. https://doi.org/10.4236/ajac.2014.510073

[29] Brown, A.M. (2001) A Step-by-Step Guide to Non-Linear Regression Analysis of Experimental Data Using a Microsoft Excel Spreadsheet. Computer Methods and Programs in Biomedicine, 65, 191-200. https://doi.org/10.1016/S0169-2607(00)00124-3

[30] El-Nahhal, Y., Nir, S., Polubesova, T., Margulies, L. and Rubin, B. (1998) Leaching, Phytotoxicity and Weed Control of New Formulations of Alachlor. Journal of Agricultural Food Chemistry, 46, 3305-3313. https://doi.org/10.1021/jf971062k

[31] El-Nahhal, Y. and Lagaly, G. (2005) Salt Effects on the Adsorption of a Pesticide on Modified Bentonite. Colloid and Polymer Science, 283, 968-974.

https://doi.org/10.1007/s00396-004-1244-7

[32] El-Nahhal, Y. and Safi, J. (2005) Adsorption of Benzene and Naphthalene to Modified Montmorillonite. Journal of Food, Agriculture and Environment, 3, 295-298.

[33] Safi, J., Awad, Y. and El-Nahhal, Y. (2014) Bioremediation of Diuron in Soil and by Cyanobacterial Mat. American Journal of Plant Sciences, 5, 1081-1089. https://doi.org/10.4236/ajps.2014.58120

[34] El-Nahhal, Y., Kerkez, M.F.S. and Abu Heen, Z. (2015) Toxicity of Diuron, Diquat and Terbutryn Cyanobacterial Mats. Ecotoxicology and Environmental Contamination, 10, 71-82.

[35] Safi, J., El-Nahhal, Y., Kaware, M., Abu-Foul, N., Tubael, K. and El-Sebae, A. (2000) Initiation of a Pesticide Environmental Extension and Public Awareness Program for Palestinian Community in Gaza Strip. Journal of Pest Control and Environmental Sciences, 8, 75-98.

[36] El-Nahhal, Y. and Hamdona, N. (2017) Adsorption, Leaching and Phytotoxicity of the Alachlor, Bromacil and Diuron as Single and Mixtures to Wheat, Melon, and Molokhia. Journal of the Association of Arab Universities for Basic and Applied Sciences, 22, 17-25. https://doi.org/10.1016/j.jaubas.2016.01.001

[37] El-Nahhal, Y. (1998) Development of Stabilized and Ecologically-Acceptable Herbicide Formulations for the Use in Hot and Sunny Regions. Ph.D Thesis, Hebrew University of Jerusalem.

[38] Nir, S., Undabeytia, T., El-Nahhal, Y., Polubesova, T., Serban, C., Rytwo, G., Lagaly, G. and Rubin, B. (2000) Optimizing Slow Release Formulations of Hydrophobic Herbicides by Organo-Clays. Israel Geological Society.

[39] El-Nahhal, Y., Nir, S., Polubesova, T., Margulies, L. and Rubin, B. (1997) OrganoClay Formulations of Alachlor: Reduced Leaching and Improved Efficacy. Proceedings of Brighton Crop Protection Conference.

[40] Nir, S., El-Nahhal, Y., Undabeytia, T., Rytwo, G., Polubesova, T., Mishael, Y., Rabinovitz, O. and Rubin, B. (2006) Clays and Pesticides. In: Bergaya, F., Theng, B.K.G. and Lagaly, G., Eds., Handbook of Clay Science, 685-699.

[41] El-Nahhal, Y., Nir, S., Margulies, L. and Rubin, B. (1999) Reduction of Photodegra- 
dation and Volatilization of Herbicides in Organo-Clay Formulations. Applied Clay Science, 14, 105-119. https://doi.org/10.1016/S0169-1317(98)00053-2

[42] El-Nahhal, Y., Nir, S., Polubesova, T., Margulies, L. and Rubin, B. (1999) Movement of Metolachlor in Soil: Effect of Organo-Clay Formulation. Pesticide Management Science, 55, 857-864. https://doi.org/10.1002/(SICI)1096-9063(199908)55:8<857::AID-PS24>3.0.CO;2-P

[43] Safi, J., Abou Foul, N., El-Nahhal, Y. and El-Sebae, A. (2001) Monitoring of Pesticide Residues on Green Pepper, Potatoes, Vicia Faba, Green Bean and Green Peas in Gaza Governorate (PNA), Palestine. Journal of Pest Control and Environmental Sciences, 9, 55-72.

[44] El-Nahhal, Y., Nir, S., Serban, S., Rabinowitz, O. and Rubin, B. (2001) Organoclay Formulation of Acetochlor for Reduced Movement in Soil. Journal of Agricultural and Food Chemistry, 49, 5464-5371. https://doi.org/10.1021/jf010561p

[45] El-Nahhal, Y. (2003) Adsorptive Behavior of Acetochlor on Organoclay Complexes. Bulletin of Environmental Contamination and Toxicology, 70, 1104-1111. https://doi.org/10.1007/s00128-003-0096-Z

[46] El-Nahhal, Y., Safi, M., Tubail, K. and Safi, J. (2013) Effect of Treated Wastewater Irrigation on Plant Growth and Soil Properties in Gaza Strip Palestine. American Journal of Plant Science, 4, 1736-1743. https://doi.org/10.4236/ajps.2013.49213

[47] El-Nahhal, Y., Abadsa, M. and Affifi, S. (2013) Adsorption of Diuron and Linuron in Gaza Soils. American Journal of Analytical Chemistry, 4, 94-99. https://doi.org/10.4236/ajac.2013.47A013

[48] El-Nahhal, Y., Awad, Y. and Safi, J. (2013) Bioremediation of Acetochlor in Soil and Water Systems by Cyanobacterial Mat. International Journal of Geosciences, 4, 880 890. https://doi.org/10.4236/ijg.2013.45082

[49] El-Nahhal, Y. and Safi, J. (2004) Adsorption Behavior of Phenanthrene on Organoclays under Different Salinity Levels. Journal of Colloid and Interface Science, 269, 265-273. https://doi.org/10.1016/S0021-9797(03)00607-6

[50] El-Nahhal, Y. and Safi, J. (2004) Stability of an Organo Clay Complex: Effects of High Concentrations of Sodium Chloride. Applied Clay Science, 24, 129-136. https://doi.org/10.1016/j.clay.2003.01.002

[51] Schecter, A., Papke, O., Ryan, J., Furst, P., Isaac, J., Hrimat, N., Neiroukh, F., Safi, J., El-Nahhal, Y., Abu El-Haj, S., Avni, A., Richter, E., Chuwers, P. and Fischbein, A. (1997) Dioxins, Dibenzofurans and PCBs in Human Blood, Human Milk and Food from Israel, The West Bank and Gaza. Organohalogen Compounds, 33, 457-461.

[52] Schecter, A., Papke, O., Isaac, J., Hrimat, N., Neiroukh, F., Safi, J. and El-Nahhal, Y. (1997) 2,3,7,8 Chlorine Substituted Dioxins and Dibenzofuran Congeners in 2,4-D, 2,4,5-T and Pentachlorophenol. Organohalogen Compounds, 32, 51-55.

[53] El-Nahhal, Y. (2017) A New Field Protocol for Determination of Forest Structure, Biodiversity and Heath Status by Means of GPS Tools: A Case Study from Gaza Forest. Open Journal of Ecology, 7, 69-83. http://doi.org/10.4236/oje.2017.71006

[54] Nir, S., Undabeytia, T., Yaron, D., El-Nahhal, Y., Polubesova, T., Serban, S., Rytwo, G., Lagaly, G. and Rubin, B. (2000) Optimization of Adsorption of Hydrophobic Herbicides on Montmorillonite Preadsorbed by Monovalent Organic Cations: Interaction between Phenyl Rings. Environmental Science and Technology, 34, 12691274. https://doi.org/10.1021/es9903781

[55] Al-Arifi, S.N., Al-Agha, R.M. and El-Nahhal, Z.Y. (2013) Environmental Impact of Landfill on Groundwater, South East of Riyadh, Saudi Arabia. Journal of Natural Sciences Research, 3, 222-242. 
[56] El-Nahhal, Y., Undabeytia, T., Polubesova, T., Golda Mishael, Y., Nir, S. and Rubin, B. (2001) Organo-Clay Formulations of Pesticides: Reduced Leaching and Photodegradation. Applied Clay Science, 18, 309-326. https://doi.org/10.1016/S0169-1317(01)00028-X

[57] El-Nahhal, Y. (2014) Development of Controlled Release Formulations of Thiabendazole. Journal of Agricultural Chemistry and Environment, 3, 1-8.

[58] El-Nahhal, Y. and Alshanti, A. (2015) Toxicity of Single and Mixtures Antibiotics to Cyanobacteria. Environment and Analytical Toxicology, 3, 1-8. https://doi.org/10.4172/2161-0525.1000274

[59] El-Nahhal, Y. and Safi, J. (2008) Removal of Pesticide Residues from Water by Organo-Bentonites. Proceedings of the 12 th International Water Technology Conference, March 27-30 2008, Alexandria, 1711-1724.

[60] El-Nahhal, Y. (2006) Contamination of Groundwater with Heavy Metals in Gaza. Proceedings of the 10 th International Water Technology Conference, March, 23-25 2006, Alexandria, 1139-1150.

[61] El-Nahhal, Y. and Safi, J. (2010) Adsorption of Bromoxynil to Modified Bentonite: Influence of $\mathrm{pH}$, and Temperature. Journal of Pesticide Science, 35, 333-338.

[62] El-Nahhal, Y. and Harrarah, S. (2013) Contamination of Groundwater and Associated Disease: Case Study from Khan Younis Governorate, Gaza, PNA. Journal of Environment and Earth Science, 3, 147-153.

[63] Rubin, B., El-Nahhal, Y., Nir, S. and Margulies, L. (2001) Slow Release Formulations of Pesticides. Patent No. US6261997 B1.

[64] Heinze, S., Yona Chen, Y., El-Nahhal, Y., Hadar, Y., Jung, R., Safi, J., Safi, M., Tarchitzky, J. and Marschner, B. (2014) Small Scale Stratification of Microbial Activity Parameters in Mediterranean Soils under Freshwater and Treated Wastewater Irrigation. Soil Biology and Biochemistry, 70, 193-204. https://doi.org/10.1016/j.soilbio.2013.12.023

[65] Bornstein, R., Safi, J., El-Nahhal, Y., Isaac, J., Rishmawi, K.H., Luria, M., Mahrer, Y., Ranmar, D. and Weinroth, E. (2012) Transboundary Air-Quality Effects from Urbanization. SJSU Report to USAID. 